\title{
TOURISM DEVELOPMENT AND THE NEW PATH OF MIGRATION IN SABAH, MALAYSIA
}

\author{
Nur Widiyanto* \& Emanuela Agra \\ *First author \\ Tourism Department, Ambarrukmo Tourism Institute, \\ Yogyakarta, Indonesia \\ (beningbanyubiru@gmail.com,agra@stipram.ac.id ) \\ DOI: https://doi.org/10.22452/brj.vol13no1.5
}

\begin{abstract}
The establishment of nature conservation projects often brings dilemmas for local communities in Southeast Asia, including in Sabah, Malaysia. On the one hand, the enactment of Kinabalu National Park has triggered the dispossession of local people from their customary lands, but on the other, it offers various economic opportunities. Employing ethnographic method, this article explores the transformation of Dusun community living in nearby Kinabalu Park and its connection to the influx of foreign migrants from Indonesia. Besides Mount Kinabalu, agriculture acts as the core of cultural pattern for the local people. However, the establishment of Kinabalu Park has offered tourism as the more profitable economic sector; therefore, agricultural lands tend to be abandoned, left for the elders and foreign workers from Indonesia. Recently, scores of Indonesian migrant families are inhabiting several villages nearby Kinabalu Park, basing livelihood primarily on vegetable cultivation. Religious factor and the advance communication technology also play the role to this migration pattern. According to direct observation, the majority of Indonesian migrants are predominantly Christians, similar to the religion of the host community. With the advent of ICT, these Indonesian migrants living in Sabah ensure that their family ties even though separated by Sulawesi Sea remains unhindered.
\end{abstract}

Keywords: tourism, migrant, transformation, Kinabalu Park, agricultural land

\section{Introduction}

In the last few decades, tourism has been placed as one promising economic sector for several countries in Southeast Asia, including Malaysia that also has engaged 
with global tourism market through the exploration of both it's eco and cultural tourism "resources". According to the Ministry of Tourism, Education and Environment, Sabah in Borneo has been visited by around 3,4 million foreign visitors and earned around MYR. 26 billion in 2016. Tourism development in Malaysia is also strongly connected to the shifting of political agenda since 1987 when the government located tourism as the major economic sector (Hjulmand, Nielsen, Vesterløkke, Busk, \& Erichsen, 2003). Therefore, eco-tourism relied on natural parks, including Kinabalu Park in Sabah, and is part of the policy to protect natural resources while supporting a stable economic growth from tourism. Coincidently, various traditional ceremonies have been a long time known as the main attraction for tourists, along with the growing numbers of foreign tourist coming to climb up Mount Kinabalu. Michel Picard (1990) offers "cultural tourism" to describe further engagement between culture and tourism development in Southeast Asia, and Bali is the example of an advanced level of such engagement. However, eco-cultural tourism development in Sabah is considered as the new development in the region. In a similar vein, the direct and in-direct engagement between local people and its fragile culture with tourism activities are something inevitable, and it may trigger various dynamics.

The arrival of modern tourism in Sabah, especially to the area nearby Mount Kinabalu is the third great changes toward the KadazanDusun community after the arrival of British colonisation and joining Malaysia Federation. It has been marked by the number of tourist arrival that drastically increased from 829 in the first year of its enactment as a national park in 1965 to 434,903 visitors in 2005, and increased to 715 . 927 by mid-2012. The establishment of the mountain as a National Park in 1964 and listed as a World Heritage Site since 2000 have significantly brought Mount Kinabalu to be a popular destination, including Bundu Tuhan Village as the main gate for the climbing activity. From the economics point of view, Sabah also receives a significant increase of tourist arrival to Kinabalu Park. Not only regarded as the sacred mountain for local people, it was also used for traditional route to sell agricultural products in the past before the connected modern transportation was established. Usually, local people needed almost a week to go there selling banana, rice or vegetables to coastal cities and brought back salt or fish. However, the basic purpose of the state park is to preserve geographical, geological, biological or historical features as a national heritage for the benefit, education and enjoyment of mankind (Nais, 1996). Thus, the policy favours physical environment and undermines the existence of indigenous communities that have been living in the area for centuries. Thus, it is the root of the problem to local people. 
From the economic point of view, the enactment of Kinabalu Park also brings various economic opportunities to the people, including those living in Bundu Tuhan village. There are two different explanations on why people from Bundu Tuhan get the privilege to access various jobs opportunities from the state park, consisting of the geographical and historical aspect. The headquarter of Kinabalu Park is located on Bundu Tuhan, including the main climbing gate Timpohon. Moreover, the people also inherit the legacy from a local legend, Gunting Lagadan, who is acknowledged as the first local people guiding the British Governor, Hugh Low, to reach the peak of the mountain in 1851. Therefore, nowadays, malim gunung (mountain guide) from Bundu Tuhan are dominating the number of listed guides and porters in Kinabalu Park, various low-level state park's jobs such as driver, gatekeeper, including homestay and restaurant nearby. Moreover, a lot of other tourism-based economic initiatives also emerge, including selling vegetables, handy-craft and the newest plan; creating the eco-tourism project in Winokok community forest, outside the Kinabalu Park.

\section{Research Problem and Objectives}

Having a deeper engagement with various tourism-based economic activities in the last few decades, local people have slowly transformed their livelihood system from agricultural to various economic initiatives that are strongly connected to tourism. However, it has resulted in a new troubling development when their agricultural lands then tend to be abandoned. Thus, these gradually-deserted lands slowly attract foreign migrants from Indonesia to come and replace the role of local farmers in managing their agricultural land. Recently, hundreds of Indonesian migrant families, especially those entering both legally and illegally from Tana Toraja and East Nusa Tenggara, live in several villages near Kinabalu Park, specifically in Kundasang, Kinasaraban and Bundu Tuhan. They came to plant various kinds of vegetables both as workers for land lords or by renting lands from local people. Understanding the connection between tourism triggering livelihood transformation among the local community as the new determining factor of hinterland-to-hinterland migration from Indonesia to Sabah is the main objective of this study. This paper is strongly aimed to answer two questions: (1) How does the development of tourism in Kinabalu Park trigger the cultural change of local Dusun people? and (2) How does the livelihood transformations of local Dusun people living in the area of Kinabalu Park determine the new path of migration to the area? 


\section{Literature Review and Theoretical Framework}

The study toward KadazanDusun as the biggest ethnic group in Sabah is dominated by the issues of ethnicity, spirituality, cultural performance and the struggle over natural resources (Barlocco, 2008). Thus, research on tourism and its connection to the impact on the local community are rare. KadazanDusun is officially used as the umbrella for the sub-ethnic groups under Dusunic root in Sabah which is Kadazan and Dusun. It is a common understanding that the Kadazans is considered as the Dusunic thas has moved to the urban area, while the Dusuns are those living in the hinterland areas, including the area nearby Mount Kinabalu. They are divided into subgroups that are distinguished by their dialect, traditional customary law (adat) and other cultural traits (Reid, 1997). KadazanDusun is often excluded from the study of indigenous groups of Malaysia where the studies are dominated for the indigenous group in the peninsula (Endicott, 2016). In the Borneo contexts, ethnicity is exercised to resist modernity and foreign capital (Boulanger, 2002). Meanwhile, Chua (2007) describes the common attitude of Bidayuh in Sarawak; well-known of anti-Muslim and Malay principles as the low-level form of resistance based on cultural-religious identity. Thus, the native group in Sabah and Sarawak can be divided into Muslims and non-Muslims, both consist of many sub-groups, each with its own language, custom and sense of identity.

The identity the KadazanDusun has received attention from various scholars. Kitingan (2012) clearly provides insight into the history, social organisation, worldview and the transformation of the group. However, she did not give a lot of attention to tourism as part of it. Meanwhile, the religious life of the KadazanDusun and rituals related to "paddy-based culture" and the important harvest festival of Kaamatan have been studied by many local scholars including Sintang (2014), Mahali and Tamring (2011), Hussin (2008), and Low and Lee (2012). These studies pose that the majority of KadazanDusun converted to Christianity or Islam, but most of them still practice rituals from the previous local belief, momolianism, according to the name of the god, momolian. Despite momolianism, or agama asal, often being considered as animistic belief, Dusun people in Mount Kinabalu area tend to take it as an important part of their cultural identity. The mountain, which is also known as Gayo Ngaran for the local people, not only acts as the central source for the local worldview, but also seen as community pride (Tay \& Chan, 2014; Toh, Awangku Hassanal Bahar Pengiran Bagul, Justin Sentian, \& Ramzah Dambul, 2012). After its establishment as a National Park in 1964 and listed as a World Heritage Site in 2000, the area grows as a popular destination marked by a significant increase of tourist arrival. 
However, tourism development has also generated neither benefits and problem to the communities. The temptation to take part in tourism industry is reflected from Sabah's government policy to enact; Halatuju, as a tourism master plan by expanding appropriate infrastructures, attracting more visitors, exploring new market and generating employment (Jaafar, Kayat, Tangit, \& Firdous Yacob, 2013).

"Heterotopic tourism" rooted in Foucault (1986) and Lefebvre's (1991) theory on heterotopia has been employed as the main tool to analyse the engagement of local Dusun people with tourism in Kinabalu Park. Heterotopic tourism is the effort to develop a form of tourism by employing cultural authenticity aimed at responding the dominant external forces. This action is a part of dramaturgy, a dualistic performance of minority group to manipulate the social situation as the way to survive (Goffman, 1959). The key concept of dramaturgy is control over the back and front stages to respond to external powers, therefore by establishing heterotopic tourism, the oppressed groups can show that they are not powerless. However, Piketty (2014) warns that globalised economic system is always political, and it cannot be reduced to purely economic mechanisms. As a part of this system, global tourism also gives its contribution towards social and economic inequalities. From this point of view, culturally, Dusun's community became victims since the early enactment of national park aimed at servicing the global environment and tourism. Thus, from a different perspective, this mainstream discourse has been challenged by the indigenous insight especially in Asia (Chang, 2015). The post-colonial tourism studies have viewed tourism as the positive landscape for the indigenous communities to strengthen themselves. In this context, heterotopia as an important background for ethnic tourism (Widiyanto, 2019). By performing the authentic cultural 'differences', the oppressed group could maintain their existence. In a similar vein, authenticity is the backbone and the most important cultural capital to engage tourism (MacCannell, 1973). Moreover, authenticity is the biggest gift searched by tourists. Consequently, endowed by the authentic culture and the attractive landscapes, villages nearby Mount Kinabalu possess important sources to produce heterotopic tourism. However, it also brings Dusun people to go deeper and have led them to transform their livelihood orientation from agricultural to tourismbased economic activities. This phenomenon then directly attracts migrants from the neighboring country to fill the abandoned lands.

\section{Methodology}

The main spirit of the research is an ethnographic study aimed to understand the dynamics of Dusun community living in the area of Kinabalu Park, Sabah when 
engaging tourism (Spradley, 2016). Thus, it demands the capability in finding and interpreting various symbols within a social phenomenon through the extensive description. Therefore, the intimate association with informants to find and to interpret significant symbols, emotion and understanding and the statement of underlying regularities of human experience have been established during the fieldwork from 2016 to 2018. The study was conducted in Sabah, Malaysia, especially in Bundu Tuhan and Kundasang Village. Primary data were collected through participant observations and in-depth interviews with local Dusun people, completed by secondary data from both the written and unwritten ones. I also have participated in the daily life of the local people and gathered the perspectives about the research topic from the state park's authority, the migrant families from Indonesia and the tourists visiting the area.

\section{Discussion and Results}

The transformation of Mount Kinabalu to be a part of modern conservation system can be traced from the era of British colonisation. In the mid-1800s, several British officers in Sabah were interested in the mountain, and it was continued by the first ascent to the top of Kinabalu by Sir Hug Low in 1851. A local person guided low from Bundu Tuhan, namely Gunting Bin Lagadan. Gunting Lagadan until today is recognised as the local legend, the pioneer of the mountain guide or malim gunung at Kinabalu. He was considered as the first person who proved that local people are the real "sons of the sacred mountain". After the first ascent to the top, several expeditions followed, mostly for ecological motives. A few decades later, it becomes the main reason for the enactment of the Kinabalu National Park in 1964 by Malaysia Federation; for its richness of environmental resources and later, paving the way for tourism (Jaafar, Ismail, \& Rasoolimanesh, 2015). However, part of this ecological richness was also previously used by local people to fulfil their daily needs; animals, rattan, firewood and also logs for building houses. In 1984, Kinabalu National Park was renamed Kinabalu Park to signify its status as a state park (The Parks Enactment, 1984). Nowadays, Kinabalu Park, covering around 753.37 sq.km, is under the Sabah Park system, which is a statutory body under the Sabah Ministry of Tourism and Environmental Development and administered through the Sabah Parks Board of Trustees.

Mount Kinabalu (4095 m) is known for having the highest peak between the Himalayas and Cartenz Pyramid in West Papua, Indonesia, surrounded by around 45 villages where around 30.000 Dusun people live. It includes around 4000 people living in Bundu Tuhan and Kundasang village. Before the enactment of the national park, people regularly conducted an annual pilgrimage to the 
summit area to give respect to ancestors and also to give their loyalty to the god. Before departing, the monolob ritual led by the shaman, or boboliyan to get permission from the ancestor's spirit was conducted in the forest area of Tinompon, nearby the climbing gate to the mountain. However, after the enactment of the national park in 1964, the access toward the mountain was neglected.

Moreover, if local people wanted to enter the mountain, they had to register and pay as is the case with other visitors. Angrily said, during an interview in December 2017, Bundu Tuhan native chief Joseph Sariman emphasised "Why must we pay to enter our own land? However, having no legal documents to support their claim over the mountain, their cultural access of the sacred Kinabalu, home of the ancestor's spirit, has officially been denied, including after the area was listed as one of the world heritages by UNESCO in 2000. This is the root of the sorrow of the local people, culturally. Ton Dietz (1996) describes that the spirit of the national park is to protect the environment, but socio-cultural access of the native groups is usually directly denied, according to its eco fascism spirit or the effort to favor environmental protection. Thus, Dusun people living nearby Kinabalu Park need a breakthrough to maintain their cultural access of the sacred mountain, and to be involved in the tourism industry provided for the economic reasons.

\section{Heterotopic Tourism in Kinabalu Park}

\section{Kakakapan id Gayo Ngaran}

The establishment of the state park has arrived as a serious dilemma for local Dusun people; on the one hand, it has brought the economic opportunity, but on the other hand, it arrived as the clearest marker for the denial of their cultural access of the mountain. Moreover, the enactment of the National Park gives a permanent restriction to continue several traditional activities such as, cutting bamboo, rattan, log or hunting and gathering food to the forest according to the traditional Dusun practices. At the end of November 2017, I witnessed one of the most important cultural events for the Dusun people in the area: Kakapan id Gayo Ngaran or Return to the Big Name. Officially, this event was accepted as a yearly event since 2010 to accommodate the spiritual access of local people of the mountain. For two days, the people would be given free access to conduct a pilgrimage to the mountain. Before hundreds of climbers from various places in Sabah depart to the mountain, the sacred monolob ritual lead by a boboliyan was conducted at the forest area nearby the climbing gate. The ritual was started by citing "rinait", the sacred Dusun text led by the boboliyan wearing the black 
traditional Dusun clothes, continued by slaughtering seven white chickens and throwing its blood to ask for permission from the spirit of the forest. Around 400 listed pilgrimage climbers joined for the Kakakapan id Gayo Ngaran 2017 and only less than half reached the summit. After walking for three to five hours, the majority decided to return to Timpohon gate. For them, the summit was not the main goal, instead, it was to celebrate and have an opportunity to enter their sacred mountains, to re-charge and strengthen their identity as a part of the Dusun community. These people almost everyday witness that "domestic and foreign climbers occupy their mountain". Therefore, having two days to freely enter the gate during the Kakakapan id Gayo Ngaran the park's authority was too valuable to miss.

The successful climbers stayed overnight at the mountain and would be welcomed the next day at the area nearby the head office of Kinabalu Park. The second day is the "big day" to welcome the climbers and to celebrate the opportunity given to the people to "go back" to the mountain. In the last few years, the event to welcome the pilgrimage climbers has become the regular tourism event namely "hari komuniti tempatan", or the community day within the state's park. It is also the arena to conduct a party for the community through the festival of traditional games, traditional culinary festival, storytelling about the history of Dusun people and Mount Kinabalu, Dusun singing contest and various traditional dances performances. During these two days, local people would not be charged RM 3.00 to enter the park, and non-local climbers would only be allowed to depart to the mountain after the event has ended. The current happiness during Kakakapan in Gayo Ngaran is the outcome of the struggle conducted since a decade ago, when a group of people from Bundu Tuhan and Kiau Village started to reclaim their sacred mountain. Joseph Sariman explains that an NGO, Global Diversity Facility facilitated the early struggle in 2010 through identifying the "biocultural" resources and traditional knowledge of the community in preserving the environment. It was followed by the official letter to demand the legal access to conduct the ritual namely Kakakapan in Gayo Ngaran in Mount Kinabalu. It was accepted in 2010, when the first ritual was conducted. Subsequently, since 2012, the park authority has officially given two days free access every December for the local people to conduct a pilgrimage to the mountain.

Heterotopic tourism is represented through the effort of strengthening cultural claim over Mount Kinabalu by conducting Kakakapan id Gayo Ngaran. The ritual has accelerated the re-awakening of their spiritual connection with the mountain and revitalising a deep cultural knowledge of how Mount Kinabalu represents the people. Moreover, it can be considered as the hidden productivity 
after denied from the ancestral land due to the process of incorporating local lands to the conservation project that bring local people to be "deterritorialising" from their land (Scott, 1998; Escobar, 2001). Hence, conducting Kakakapan id Gayo Ngaran is the strategy to offer an alternative way to deal with homogenisation in terms of environmental policy and the dominant role of the world religion: Islam and Christianity. According to Lefebvre, it can be located as the mode of autosuggestion by seeing the state's policy as a site to struggle. By reclaiming the mountain for the pilgrimage site, people have given three local symbolic resistances toward the external hegemony. First, if the government perceives that Mount Kinabalu is important for the ecological protection and tourism agenda, people challenge by raising the alternative discourse; a mountain is a sacred place from the Dusun's cosmology. It is the untouchable landscape for "going home" after the people die, the home of the sacred and respected invisible figures. Secondly, through Kakakapan id Gayo Ngaran, people have raised the discourse of the utopic figures rooted in momolianism to challenge the other "utopic" figures brought by Christianity and Islam. Thirdly, through transforming the ritual to be one of the tourism agendas, it describes the effort to maintain the steady economic access through tourism, besides intensively engaging climbing activity on Mount Kinabalu.

\section{Leaving Agricultural Land to Serve Visitors}

Discussions on the development of eco-tourism in Kinabalu Park are closely related to the existence of climbing activity on Mount Kinabalu. Standing as the highest mountain in Southeast Asia, Kinabalu becomes a famous destination for climbers and researchers in the region. Afiqah, a local visitor from Selangor nearby the head office of Kinabalu Park claimed to be interested in exploring more about the local culture after hearing series of myths from her malim gunung. Afiqah witnessed that the guide was seriously citing a prayer using the local language before entering the summit area. Consequently, she understands that Kinabalu is a sacred landscape for the people. The main roles of a mountain guide are to assist the visitors to reach their aims in the mountains, and secondly to increase the guests' knowledge on the destination visited (Ching, 2009, p. 83). However, the behaviour of the local guides displays their cultural connection to Mount Kinabalu as both the place to make a living and the sacred place according to their local beliefs.

Geographically, Bundu Tuhan and Kundasang are strategically located, directing would-be mountain climbers to pass the villages. The people have a strong root in agriculture, thus the majority of people in these villages are farmers. 
However, a lot of young men also work as a mountain guide, porter and daily worker at Kinabalu Park, including at several restaurants nearby. The number of mountain guide has significantly increased from 20 malim gunung in 1978 to 171 in 2005, and almost 260 in 2017. Bundu Tuhan has supplied most of the guides and porters for the climbing activity in Bundu Tuhan. In 2017, from 260 malim gunung and porters that are legally registered in Kinabalu Park office, around 180 are from Bundu Tuhan. The existence of malim gunung predominantly from Bundu Tuhan is connected to the history of Gunting bin Lagadan as it has been previously mentioned. Therefore, inspired by Lagadan, young generation proudly locate themselves as the real sons of the mountain, thus more entitled than others to work as the malim gunung. Moreover, the Park Enactment No. 10 of 2002 regulates that all climbers should be accompanied by a local mountain guide, stating the legal proportion is 3:1, meaning three climbers should be accompanied by one malim gunung. It directly gives a lot of new opportunities to the local people to be involved in the climbing activity.

Living in the hilly area and endowed by the important legacy from Gunting Lagadan, almost all young men in Bundu Tuhan have experienced the role of a malim gunung or at least a porter. After finishing their study at senior high school, the local boys would go to Timpohon, the climbing gate to work as malim or porter. The job serves as a temporary activity while waiting to get another job or obtain a higher level of education. Roystone Tiam, who now works as the international relation staff at Sabah Parks Head Office once worked as malim gunung for almost 3 years. Having an extensive network to the mountain guide activity in Kinabalu Park has made it is easier for the new generation to get access to the job. Thus, people from Bundu Tuhan are considered as the first layer, followed by the neighbouring village of Kiau and Kundasang as the second layer, and the rest consists of several villages surrounding the mountain. Besides being malim gunung or porters, dozens of Bundu Tuhan and Kundasang people also work as the gatekeeper, at the spark's office, restaurants and staff in several lodges along the climbing route to the top of Kinabalu. Others even operate their homestay or travel companies, which are also connected to tourism in the area.

Guiding the climbers to the summit is not only about earning RM 200 for one climbing trip, but also to prove that they are the sons of the mountain. Thus, it has a cultural purpose; to make a regular pilgrimage to the "mecca" of their beliefs, their sacred land, besides merely financial purposes. The mountain itself has long history of external domination, neglecting people from its sacred land. These points illustrate that being a mountain guide is very important in order to protect their cultural bond with the mountain. Therefore, climbing activity is a pilgrimage and a job at once. An active malim gunung can guide both the local and 
foreign climbers twice a week, so from the financial perspective, it is a profitable job, compared to being a vegetable farmer. According to Peter Pausai, a local young man working at Tahubang Lodge, growing vegetables need much cost for the land preparation, seeds, growing crops and the uncertain post-harvest vegetables price. From the cultural point of view, the engagement between local people and tourism development reveals two important things; to maintain the legacy of the legendary Gunting Bin Lagadan and to get the direct access to the sacred mountain. In this case, climbing activity has provided an opportunity to bridge the need to maintain the ties to certain cultural identity with the demand to establish eco-tourism in the area. Therefore, cultural ground has been effectively exercised; when the demand of ecological protection and tourism agendas can effectively be compromised with the need of producing cultural expression.

Departing from the idea of both Foucault and Lefebvre on heterotopia as the space to escape and to respond to the hegemonic forces, tourism has been taken as the alternative avenue to show the effort of local Dusun people to maintain their cultural identities. Moreover, it is the breakthrough to survive from the hegemonic powers; the Malay (and Islam) politics dominating Dusun groups in the religious and political issues, and the national park that has effectively denied the access of these groups to their ancestral land. According to Adams's study on Sherpas community in Nepali Himalaya, authenticity is the important cultural capital to develop and maintain the identity through tourism (Adams, 1996, p. 40). Thus, in Kinabalu Park area, cultural identity is exercised through tourism as the alternative avenue. Employing cultural authenticity is the strategy to strengthen their claim over the ancestral land which have been legally taken by the government through establishing the state's park. Therefore, heterotopic tourism plays its important role as the "in-between stage" to bridge the back region-the need to maintain local belief, and the front region - the involvement in the tourism market. However, this movement through shifting from agriculture to tourism has resulted in other consequences; the abandoned agricultural lands left for the elders and subsequently for foreign migrants from Indonesia.

\section{Crossing the Sea to Grow Vegetables: Indonesian Migrants in Ranau}

Faridah Dambul is a Dusun woman who was born in Bundu Tuhan in 1956. She converted to Islam from momolianism-she called it pagan in early 1970. Nowadays, she manages a homestay in Kundasang namely Sunduan Lodge. Having a family house in Bundu Tuhan, Faridah regularly returns to Bundu Tuhan to meet her big family. In the early June of 2017, I stayed two nights at Faridah's homestay, shared a kitchen with a Belgium family who had spent three days at the lodge. 
Amazingly, during three days in Faridah's house, I met five Indonesians, three of whom were from Tana Toraja. They consisted of two men namely Hendra and Alex, and Nina, a 21-year-old woman. The two others were men from East Nusa Tenggara province, Julius and Agustinus. Nina has worked as a domestic helper for two years and sometimes helps Alex and Hendra to grow vegetables on Faridah's farmland nearby the homestay. Nina decided to move to Ranau after getting divorced with her husband in Toraja, and invited to come by her cousins Hendra. Hendra also sent a lot of pictures through whatsapp describing Kundasang as the alternative promising place to continue her life. Meanwhile, Julius and Agustinus have been living for five years in Kundasang, growing cabbage and tomatoes after renting a farmland from Faridah's younger brother. In the first three years in Sabah, they worked for the landlord to grow vegetables, and during the third year, the landlord decided to give to rent out his land. Before living in Kundasang, these Indonesian migrants worked at the oil palm plantation near Tawau and came to Mount Kinabalu area after getting asked by the other Torajan who had been living and growing vegetables in Bundu Tuhan since 2008.

The next day, I was invited to visit the Community Learning Center (CLC), a semi-formal school for the Indonesian children in Kampung Cinta Mata, Kundasang, Ranau Sub District, and witnessed around 80 Indonesian children in the school. They were children from hundreds of Indonesian migrants mainly living in three villages; Kundasang, Bundu Tuhan and Kinasaraban. Most of them are from Tana Toraja in South Sulawesi and Flores, East Nusa Tenggara province in Indonesia. These two areas share several similarities to Ranau; situated in the highland and rooted in agriculture, including vegetable cultivation. The Indonesians predominantly came to Sabah to grow vegetables, as they did in their home country. From the religious point of view, the majority of these migrants are Christians, similar to the majority religion in the area. This pattern is different from the biggest number of Indonesian migrants living in the coastal areas of Sabah such as Kota Kinabalu, Tawau or Sandakan, who are Muslims coming from the coastal areas. The majority of these "low land" migrants work in various informal sectors; bus/taxi driver, restaurants, fishery, domestic helpers and palm oil plantations. Mansur, one of the Indonesian migrants from Majene, West Sulawesi whom I met at Tawau Harbor, explained that the Indonesian migrants both from the coastal of highland would cross the Sulawesi Sea and usually stopped in Nunukan before crossing to Tawau. Then, the Muslims migrant scattered to the several coastal areas such as Lahad Datu, Sandakan, Tawau, Kota Marudu or Kota Kinabalu to work at several informal jobs, including to the palm oil plantations, meanwhile, the Christian from Tana Toraja and Flores directly moved to Ranau to grow vegetables. However, some Muslim families from the coastal areas of 
Indonesia also join to migrate to the Kinabalu Park area, especially to Kundasang Village that also inhabited by the local Muslim community. Mansur who have lived in Tawau for almost ten years emphasised that these migrant paths have existed since the first time he arrived in Tawau in 2009.

In a similar vein, Peter Pausai, a local Dusun man from Bundu Tuhan emphasises that a great transformation has occurred in the area of Kinabalu Park since the past two decades, especially in terms of livelihood system. Having a strong root in agricultural activity through growing paddy and vegetables, things have changed along with the involvement in the tourism sector. It is also marked by the influx of Indonesian migrants to fill the empty room left by the young generation of local people who prefer working in the tourism sector; such as being malim gunung, porters, guides or homestay workers nearby the headquarter of Kinabalu Park. A lot of landowners in Bundu Tuhan opted a similar path as Faridah by developing a mutual partnership with the Indonesians. Faridah has almost one hectare of land in Kundasang and she has employed three Indonesian workers to cultivate cabbage and potatoes on her land in the last ten years. Faridah emphasises that besides the fact that local workers are not sufficient anymore, her Indonesian workers are the ones she could rely on both for their skills, affordable payment and their attitude.

Thus, many of the other landowners in Bundu Tuhan also prefer to lend their agricultural lands for around RM 1500 every planting season (around 4 months) to the Indonesian migrants rather than managing the lands themselves. This is due to the significant increase of production cost to grow vegetables, consisting of several fixed costs within the agricultural business; buying seeds, paying for workers' salary and buying pesticides. Therefore, conducting agriculture-based business is considered as a dangerous game because, during harvesting time, the price of vegetables could drastically drop. Furthermore, many local people prefer to be involved in the tourism-based business as mentioned above, such as earning around MYR 200 to 400 for two days guiding the climbers to Mount Kinabalu or by working at several homestays, hotel or restaurants linked to the Kinabalu Park. Evidently, being a malim gunung is considered much more profitable rather than facing uncertainty from managing their land themselves. This tendency corresponds to the need of the Indonesian migrants who came to Sabah to earn money by relying on their skills and knowledge in growing crops, as they did in their home country.

Consequently, having paddy as one of the central cultural patterns, Dusun people in Kinabalu Park area have gradually lost their connection to the land, leaving their land that in the past was used by their ancestors to grow padi hutan; a term for dry paddy cultivated in the hilly areas nearby Mount Kinabalu. They 
have unwittingly given the rights to cultivate those lands to the people coming from Indonesia who does not have any sense to maintain certain cultural pattern with paddy or Mount Kinabalu. Therefore, only a few old farmers in Bundu Tuhan such as Sotoy (86 yo), Peter's grandmother, who still head out to her farming land every morning to attend to her crops. Meanwhile, the majority of the younger generation will depart to Kinabalu Park or Kota Kinabalu, or even Kuala Lumpur, to work in non-agricultural fields. Peter Pausai was smiling when I asked, "When was the last time you visited your kebun?" He then answered, "It might have been a year ago when I went there to pick up my nenek because it was going to rain hard soon". However, for a community that considers paddy and traditional agricultural activity as a central cultural practice, this transformation is a serious challenge. Having slowly lost paddy as the symbol of authenticity, the cultural identity of Dusun people in the area is merely symbolised through the pilgrimage to the sacred mountain.

KadazanDusun society is known for its ability to survive within different eras, times and circumstances and nowadays has arrived at the crossroad between traditionalism and modernity (James, 1999). Tourism development in Kinabalu Park is an instrument of globalisation coming to undermine various traditional values, symbolised on momolianism and its practices. Tourism has also changed the economic orientation of people, effectively transformed land-based activity rooted in paddy as the central pattern, into the tourism-based economy. Partly claiming the sacred mountain Kinabalu while leaving agricultural land have indicated that the community has exercised their Dusunic authenticity to guarantee the access over both cultural identities and a steady livelihood sector provided by tourism. However, on the other hand, they could enjoy a steady position to dominate many economic opportunities provided by the increasing numbers of visitors coming to Kinabalu Park within the last few decades. The successful action in culturally claiming the mountain by regularly conducting Kakakapan id Gayo Ngaran can be considered as the half-hearted cultural revivalism, which is not merely directed by the cultural motives, but also the rational-economic motives to have bigger opportunities by engaging in the tourism industry. However, this transformation has paved the way for the development of a new migration path; from hinterland to hinterland marked by the influx of the Indonesian migrant coming to the area togrow vegetables on the abandoned agricultural lands.

\section{Conclusion}

The encounter between local culture and tourism development in the area of Kinabalu park produces several transformations amongst the local Dusun people 
in the nearby villages, including Bundu Tuhan and Kundasang in terms of livelihood orientation. The promising economic role of tourism in providing several economic opportunities has been combined with the need to maintain the cultural connection to Mount Kinabalu to produce the heterotopic tourism in the area. Realizing that tourism is one key driver for economic progress, the effort to strengthen cultural recognition over the ancestral land has been conducted without opposing tourism. Instead, it has been carried out through collaborations with tourism. However, the more in-depth engagement with tourism-based economic sectors has resulted in the abandonment of agricultural lands, and directly attracted the influx of foreign migrants, especially from Indonesia, to replace local farmers in taking care and managing the lands. Thus, the mutual partnership between Dusun people in Kinabalu Park area and the Indonesian migrants, especially from Tana Toraja and Flores, can be considered as one fruit of the long engagement between local culture and tourism development in the area of Kinabalu Park.

\section{Acknowledgements}

We thank the Indonesian Consortium for Religious Studies (ICRS), Gadjah Mada University, Yogyakarta and STIPRAM Yogyakarta for all the facilities and support during the research both in Sabah and West Java from 2016 to 2018. We also thank the Institute of Thai Studies, Chulalongkorn University, Bangkok for the opportunity to expand the research to the Urak Lawoy community in Phuket, Thailand and the KeMenristek DikTi, Republic of Indonesia for supporting the research through the Penelitian Disertasi Doktor (PDD) Research Programme for the first author. We also would like to give a bunch of appreciation to all Dusun community in Bundu Tuhan, Kundasang and Kiau Village in Ranau Sub-District, Sabah, colleagues from KadazanDusun Cultural Association (KDCA) and University Malaysia Sabah (UMS) for giving their hands during the research: come as a guest, return as family.

\section{References}

Adams, V. (1996). Tigers of the Snow and Other Virtual Sherpas: An ethnography of Himalayan Encounters. New Jersey: Princeton University Press.

Barlocco, F. (2008). Between the Local and the State: Practices and Discourses of Identity among the Kadazan of Sabah (East Malaysia). Doctoral thesis, Loughborough University, United Kingdom 
Boulanger, C. L. (2002). Inventing Tradition, Inventing Modernity: Dayak Identity in Urban Sarawak. Asian Ethnicity, 3(2), 221-231.

Chang, T. C. (2015). The Asian Wave and Critical Tourism Scholarship. International Journal of Asia-Pacific Studies, 11 (S1), 83-101.

Ching, G. H. (2009). Mountain Guiding in Kinabalu Park: An Evaluation of Visitor Satisfaction. Borneo Research Journal, 3, 81-91.

Chua, L. (2007). Fixity and Flux: Bidayuh (Dis)engagement with the Malaysian Ethnic System. Ethnos, 72(2), 262-288.

Dietz, T. (1996). Entitlements to Natural Resources Contour of Political Environmental Geography. Utrecht: International Books.

Endicott, K. (Ed.). (2016). Malaysia's Original People: Past, Present and Future of the Orang Asli. Singapore: NUS Press.

Escobar, A. (2001). Culture Sits in Places: Reflections on Globalism and Subaltern Strategies of Localization. Political Geography, 20(2), 139-174.

Foucault, M. (1986). Of Other Spaces: Utopias and Heteropias (J. Miskowiec, Trans.). Diacritics, 16(1), 22-27.

Goffman, E. (1959). The Presentation of Self in Everyday Life. London: Penguins Books.

Hjulmand, L. G., Nielsen, U., Vesterløkke, P., Busk, R. J., \& Erichsen, E. (2003). Tourism as a Development Strategy in Rural Areas Adjacent to the Crocker Range National Park, Sabah, Malaysia. Retrived June 22, 2018, from http://www. arbec. com. my/pdf/art8janmar03. pdf

Hussin, H. (2008). Performing Rice Farming Rituals by Penampang Kadazan of East Malaysia: Between Sacred Ritual and Secular Performance. JATI Journal of Southeast Asian Studies, 13, 173-190.

Jaafar, M., Ismail, S., \& Rasoolimanesh, S. M. (2015). Perceived Social Effects of Tourism Development: A Case Study of Kinabalu National Park. Theoretical and Empirical Researches in Urban Management, 10(2), 5-20.

Jaafar, M., Kayat, K., Tangit, T. M., \& Firdous Yacob, M. (2013). Nature-based Rural Tourism and Its Economic Benefits: A Case Study of Kinabalu National Park. Worldwide Hospitality and Tourism Themes, 5(4), 342-352.

James, G. (1999). Whither the KadazanDusun: The Next Millennium. Kota Kinabalu: KadazanDusun Cultural Association Press.

Kitingan, J. P. (2012). Kadazan Dusun. Kuala Lumpur: Institute Terjemahan dan Buku Malaysia.

Lefebvre, H. (1991). The Production of Space (N. Donaldson-Smith, Trans.). Oxford: Basil Blacwell. 
Low, K. O., \& Lee, Y. F. (2012). Investigating the Relationship between Kadazandusun Beliefs about Paddy Spirit, Riddling in Harvest Time and Paddy-Related Sundait. Jurnal Malim, 13, 71-97.

Mahali, S. N., \& Tamring, B. A. (2011). Plurality dalam Kearifan Lokal di Sabah. Kota Kinabalu: University Malaysia Sabah Press.

MacCannell, D. (1973). Staged Authenticity: Arrangements of Social Space in Tourist Settings. American Journal of Sociolog, 79(3), 589-603.

Nais, J. (1996). Kinabalu Park and the Surrounding Indigenous Communities, Malaysia (South-South Cooperation Program on Environmentally Sound SocioEconomic Development in the Humid Tropics Working Paper No. 17).

Picard, M. (1990). "Cultural Tourism" in Bali: Cultural Performances as Tourist Attraction. Indonesia, 49, 37-74.

Piketty, T. (2014). Capital in the Twenty First Century (A. Goldhammer, Trans.). London: Harvard University Press.

Reid, A. (1997). Endangered Identity: Kadazan or Dusun in Sabah (East Malaysia). Journal of Southeast Asia Studies, 28(1), 120-136.

Scott, J. C. (1998). Seeing Like a State: How Certain Schemes to Improve the Human Condition Have Failed. New Haven: Yale University Press.

Spradley, J. P. (2016). The Ethnographic Interview. Long Grove, Illinois: Waveland Press.

Sintang, S. (2014). Peaceful Co-Existence in Religious Diversity in Sabah, Malaysia. Global Journal of Human-Social Science: Art \& Humanities-Psychology, 14(1), 67-77.

Tay, K. X., \& Chan, J. K. L. (2014). Tour Operator Perspectives on Responsible Tourism Indicators of Kinabalu National Park, Sabah. Procedia-Social and Behavioral Sciences, 144, 25-34.

Toh, P. S., Awangku Hassanal Bahar Pengiran Bagul, Justin Sentian, \& Ramzah Dambul. (2012). Developing and Promoting a Highland Community Livelihood for Sustainable Tourism: The Case of Kg. Bundutuhan, Ranau, Sabah. Geografia-Malaysian Journal of Society and Space, 8(5), 94-99.

Widiyanto, N. (2019). Indigenous Religion Revivalism and Tourism Development in Indonesia and Malaysia; A Study on Kasepuhan Ciptagelar in West Java and Bundu Tuhan's Dusun Community in Sabah. Doctoral dissertation, Gadjah Mada University, Yogyakarta, Indonesia. 